\title{
A 'placeful' station? The community role in place making and improving hedonic value at local railway stations.
}

Matthew Alexander*

Kathy Hamilton

Department of Marketing

Sir William Duncan Building

University of Strathclyde

130 Rottenrow

G4 0GE Glasgow, UK

FAX: $+44(0) 1415522802$

matthew.j.alexander@strath.ac.uk Tel: +44(0) 1415483949

kathy.hamilton@strath.ac.uk Tel: +44(0) 1415483240

*Denotes corresponding author

\begin{abstract}
In recent years, railway stations have come to be seen as non-places within society, points of transit and nothing more. The role of the station in place making is disputed with stations seen as both creating and destroying a sense of place within a community. Our study is located within the railway stations of Scotland and explores how local communities have been empowered to reclaim, customise, and re-appropriate stations to simultaneously create a sense of place and better promote their community to the outside world. Drawing on ethnographic research we refute the notion that stations are somehow 'placeless'. We show how through a process of legitimisation, a sense of ownership and appropriation of the station environment, communities are able to transform the station, improving hedonic value and recapturing a sense of place.
\end{abstract}

Keywords: railway stations, community, placelessness, placefullness 


\section{Highlights}

- We explore the local community role in regenerating Railway Stations.

- Community appropriation of stations leads to an increased sense of ownership.

- Through community involvement a sense of place is engendered and developed.

- Station adoption results in place transformation and feelings of placefullness 


\section{A 'placeful' station? The community role in place making and improving hedonic value at local railway stations.}

\section{Introduction}

'The railway station is one of the rare public buildings produced by the industrial revolution which illustrates admirably, over a hundred and fifty years, the gropings, fluctuations and transformations of our Western society. Stations reveal the myths and realities of the epic times we live in. A veritable microcosm of industrial society, a public place where all social classes rub shoulders, the station has been throughout its history at the heart of the present, the many faceted mirror of a striking array of achievements' (Dethier, 1981 p.6)

In the UK, arguably the birthplace of the modern railway, railway stations have a deep rooted sense of history. Railway stations are gateways (reference withheld for review) or 'attractive points of entry' (Pels and Rietveld, 2007, p.2044) that link urban environments to the outside world and play an important role in place marketing (Warnaby, 2009b). However, outside of large cities with their grand flagship railway stations the role of the urban or rural station in society receives less attention but is, arguably, no less significant. In our research we investigate the importance of local railway stations to their communities and explore how legitimised community involvement at railway stations can contribute to a reclaimed sense of place, or placefullness as we will refer to it.

The importance of place is central in modern society and operates in us as the "geographical component of the psychological need to belong somewhere, one antidote to a prevailing alienation" (Lippard, 1997). The growing importance of place in society is increasingly recognised at the corporate level with strategies such as localisation (Värlander, 2007) enabling firms to better understand a market, and provide customers with offerings which appeal to specific local demands. However, the implication here is merely that company representatives be given some degree of flexibility to adapt 'global' strategies to fit the 'local'. The idea of placefullness in these contexts is deliberately embedded by an outside agent in order to make an offering 'fit' a local setting (Williams et al., 2004). We argue that 
placefullness is, in fact, something that can develop from within a community and this paper aims to explore the mechanisms by which communities can create a sense of placefullness at local railway stations.

Our study explores the railway stations of Scotland and how local communities are empowered to reclaim, customise, and re-appropriate stations to simultaneously create a sense of place and better promote their community to the outside world. The paper proceeds by exploring the role of the railway station in local economies and considering competing arguments of place and 'non-place'. We then consider the potential for the community to play an active role in creating a sense of place (or placefullness). We use ethnographic methods to consider the relationship between a public transport provider and community groups who 'adopt' their local railway stations. We use the term community to denote community of place where members are connected through their geographic location. Our research shows that, with firm support, community groups are legitimised and make a meaningful contribution to their localities by creating placefullness and transforming stations to sites of heritage, aesthetic value and social support.

\section{The Railway Station in Society}

\subsection{Railway Stations: Place and Non-Place}

During the rapid growth of the railways in the mid to late $19^{\text {th }}$ century, stations grew from "a 'gate' at the city fringe to the status of palace in the very heart of the city" (Maillard, 2001, p.14). Increasingly, these flagship buildings took on an important and symbolic role in urban development (Warnaby, 2009b) and phrases such as 'volcanos of life', 'palaces of modern industry' and 'cathedrals of humanity' (Dethier, 1981, p.6) all suggest emotive and significant roles in society. Additionally, the architectural refinery of many railway buildings 
served "to communicate the achievements of the railway to a broad public" (von Buch, 2007, p.267).

However, in the post war years the railway industry, particularly in the UK, declined with the infamous 'Beeching cuts' exemplifying negative attitudes towards railways and in line with an increasingly car based society (Wolmar, 2007). The latter part of the $20^{\text {th }}$ century saw lines closed, stations de-manned and station buildings demolished. This attitude is summed up by Flanders and Swann in their song 'The Slow Train' which mourns the loss of many local railway stations "no churns, no porters, no cat on a seat".

In recent years various authors have acknowledged the positive impact stations have on cities from an economic perspective and also as an attractive location for service industries (Pels and Rietveld, 2007, de Graaff et al., 2007). Grand buildings once cited for closure like St Pancras in London have been renovated and given a central role in the development of a high speed European network, mirroring the activities of the French TGV railways in the latter part of the $20^{\text {th }}$ century (Maillard, 2001, p.14). Indeed, "by reappropriating some of the architectural archetypes of the past, the modern station is starting over as a symbol of travel and a pleasant place for the customer" (Maillard, 2001, p.14).

Changing traveller's mode of travel from car to rail is seen as a key strategy of the EU (Brons et al., 2009) and improving transit and terminal service quality is recognized as an important factor influencing traveller behaviour (Cascetta and Cartenì, 2014). The recent mobilities paradigm suggests that time spent in inactivity (such as waiting at stations) is as important as the time spent in motion (Bissell, 2009). Ultimately, Warnaby (2009b) sees transport infrastructure as having significant potential in creating awareness of - and changing perceptions of - places in the minds of a target audience. 
Railway stations perform a range of functions in society beyond the instrumental activity of facilitating the boarding of trains in that, "they are part of community life" (Edwards, 1997, p.26). Station design, therefore, served the communities in which they were set and station architecture and embellishment "mirrored the different roles that the railway played in society - economically, politically and socially" (Edwards, 1997, p.26). Railway stations (unlike airports perhaps) need to be better integrated into a community and are characterised by heterogeneity (Bissell, 2009). Stations act as a symbolic presence (Edwards, 1997, Lee, 2003) and railways can lead to economic growth and the revitalization of urban areas (Edwards, 1997). In rural areas stations:

Do much to sustain small towns in the countryside by reinforcing the local economy and providing a magnet, albeit on a small scale, for future growth. Country stations are often the main social and business focal point of rural areas, locations where tourist services are promoted... both a means of access to other places and a centre for local enterprise and cooperation. (Edwards, 1997, p.42)

However despite the societal importance of the railway station noted above, the gradual retraction of the railway in the $20^{\text {th }}$ century, and a more functionalist approach taken by architects and planners (Dethier, 1981), it is unsurprising that railway stations can be seen in a negative light, a non-place:

"Railways, like other modern communication and transportation systems, pose a theoretical dilemma. Do they alienate or destroy a sense of place...or enable new connections to be made? If the latter is the case, do these new experiences of place sufficiently compensate the loss of more traditional sensibilities?” (Bishop, 2002, p.298)

In Augé's (2008, p.63). work the railway station is seen as an archetypal non-place, "a space which cannot be defined as relational, or historical, or concerned with identity". 
However recent developments in society such as the heritage movement ${ }^{1}$ have reassessed the way in which buildings are valued within society, "we are now beginning to recognize the beauty and value of our heritage from the industrial age" (Stratton, 2000, p.3) and regenerating it for diverse uses beyond that which it was originally intended. In the context of the railway station built heritage and sense of place is increasingly important and can underpin wider redevelopments and improve the station environment (Maillard, 2001) through, for example, distinctive architecture or public art (von Buch, 2007, Edwards, 1997, Harrison, 1981). Stations embrace a wider purpose "with retail, social and cultural facilities enclosed within its shell... an urban venue worthy of a visit in its own right" (Edwards, 1997, p.173). This sense of place is further explained by Cascetta and Carteni (2014, p.50) who associate architectural and aesthetic quality with hedonic value which they define as "the pleasure that travellers receive from being in an environment transmitting pleasurable sights, ranging from art pieces, to internal and external station architecture”. Indeed, Cascetta and Carteni found that passengers were prepared to wait 7 minutes longer and travel 10 minutes further to reach a station with a higher aesthetic value.

In both rural and urban station contexts the benefits of creating a sense of place and increasing hedonic value suggest a role for engaging communities in transformational activities particularly when stations are not major hubs or somehow less worthy of investment. The community role in local area re-invention and regeneration is already recognised with Stratton (2000, p.3) promoting the notion of "re-inventing communities where people already live, and recognize the value of the investment both in people and the built environment which already exists". We therefore proceed to consider the potential

\footnotetext{
${ }^{1}$ In the railway world represented by organisations such as The Railway Heritage Trust http://www.railwayheritagetrust.co.uk/
} 
contribution that the local community might make to the creation of a sense of place in railway stations.

\subsection{The Role of the Community in Regeneration and Place Making}

Seamon (2008, p.43) suggests that the study of place attachment requires an understanding of the complexity of place "as it is experienced and fashioned by real people in real places" and that individuals and groups create a sense of place both deliberately and unselfconsciously in both non-descriptive places as much as those with stronger associations.

Citizen participation has long attracted the attention of researchers and there are several approaches to characterise the various forms. For example, Arnstein's (1969) ladder of citizen participation is a typology of eight types arranged by the extent of citizen power in decision making, ranging from nonparticipation (Manipulation, Therapy) to degrees of tokenism (Informing, Consultation, Placation) to degrees of citizen power (Partnership, Delegated Power, Citizen Control). Susskind and Elliott's (1983) review of participation in Western Europe reveals three distinct forms of relationship between residents and elected officials: (1) paternalism involves a highly centralised approach to municipal decision making; (2) conflict occurs whenever resident groups seek control over particular decisions although centralised decision making dominates; (3) coproduction involves negotiation between decision makers and residents. Susskind and Elliott (1983) note that better results arise from a more collaborative approach and outline various strategies that support a shift towards coproduction. Since this time, others have defended a collaborative approach, defined by Brand and Gaffikin (2007, p. 287) as "an inclusive dialogic approach to shaping social space.” For example, Shandas and Messer's (2008) investigation of community involvement in environmental stewardship reveals how participation can create empowerment and a stronger connection with the natural environment. However, 
collaboration is not without difficulties. As Healey (1997, p. 199) states, "the challenge of managing co-existence in shared spaces reflects and expresses in acute form the wider challenge of the search for forms of governance appropriate to a world of global relations within which local action matters." Further, Brand and Gaffikin (2007, p. 307) suggest that collaborative planning is difficult to realise given "the social untidiness of the contemporary world." The dynamic and diverse nature of the civic infrastructure means that governance processes are "unique constructions in specific situations" (Healey, 2003, p. 110), reinforcing the need for further studies in this area.

While some forms of participation are formally organised, others are more self-organised. For example, in a study of street art, Visconti et al (2010) explore how active consumers create a sense of belonging and dialogue around private, commercialized places which are in a sense 'offered back' to the community as a public good. Citizens engaging in street art are 'curators' whose actions both enhance the character of a site and empower its stakeholders. These urban curators "sidestep the constraints imposed by the 'myth' of the architect, by bureaucratic building law, and by market economics, to create relationships of 'greater connectedness' between people and environment" (Visconti et al., 2010, p.526). The authors observe two main outcomes from the reclamation of public goods: firstly artistic reenchantment leads to community revival and citizen empowerment; secondly the process extends beyond local inhabitants to include external visitors as the renewed sense of place contributes to a "destination window [building] self-esteem within the locale, revitalizing all that it touches" (Visconti et al., 2010, p.525).

However Visconti et al's paper addresses community activity essentially guerrilla in its nature, the conscious reclamation of territory which is privately owned and subverting it as a public good. There is implicit conflict here between the private firms who own the 'space' and the public who may wish to reclaim it as 'place'. Visconti et al.'s informants appear to 
understand place as something that must emerge organically and according to local agendas which are familiar to the local community but not necessarily of interest to private organizations. Indeed the authors observe that:

"only when stakeholders share the same understanding of street democracy, which gives back place to its owners, can the consumption of a commons that is equally meaningful and enacted be fully appreciated" (Visconti et al., 2010, p.525).

Although not specifically related to community engagement, Thompson et al (2012) note how the railway experience is generated through complex interactions between the railway and the people that use it. Rail travel is a socio-technical system and therefore social interventions may be needed to maintain positive experiences. Thompson et al (2012) explore problems associated with vandalism and graffiti and how unkempt station environments can have a negative effect on passenger safety perceptions and discourage utilisation. Drawing on broken windows theory and its zero tolerance approach towards vandalism and associated benefits (see Thompson et al (2012)) the authors include community engagement as one of a range of possible strategies to address anti-social behaviour. In our study we seek to explore how the attachment to a 'place' seen as local, and the sanctioned appropriation of stations by local residents can lead to a range of benefits.

\subsection{First ScotRail and Adopt a Station: An ethnographic study}

The setting for our research is 'Adopt a Station,' part of the franchise commitment of First ScotRail who operate the majority of rail services in Scotland. The scheme has its roots in the community rail movement in England in the 1990s where the Association of Community Rail Partnerships $(\mathrm{ACORP})^{2}$ supports a federation of over 50 community rail partnerships and rail promotion groups. ACORP describes itself as an 'organisation of 'do-ers', focused on practical initiatives which add up to a better more sustainable local railway'. ACORP's work

\footnotetext{
${ }^{2}$ http://www.acorp.uk.com/index.html
} 
centres on improving stations and train services with a particular focus on integrating rail travel with other forms of local transport; station adoption is one part of their wider work. In Scotland Adopt a Station operates as a collaborative partnership between ScotRail and community groups or individuals who request, or are invited to 'adopt' local railway stations to find uses for vacant accommodation and encourage a wide range of gardening activity on station platforms (ScotRail, 2012). The scheme is largely funded by ScotRail who reimburse all costs associated with gardening at the station (e.g. paying for any flowers, containers and reconnecting disused water mains). Apart from remedial work to ensure accommodation is safe and properly connected to electricity, drainage etc. ScotRail do not fund costs to make accommodation habitable or pay local authority rates, they do however offer the space rent free. As a result adoption groups often seek funding from the wider community through donations, operating small businesses (e.g. bookshops) or securing funding from larger funding bodies (including the Heritage Lottery Fund and the Railway Heritage Trust see table 1 for further detail). Since its official launch in 2005 more than 200 (out of 343 stations in total) have been adopted by individuals, community councils, schools or dedicated adoption and a range of other community groups.

Adoptions are found throughout Scotland and in stations of varying size with both urban and rural locations represented and community uses varying from station to station. Alongside gardening (the most popular activity) adopters have opened bookshops; ex-station master flats have been converted to heritage centres and art galleries; old offices have been converted into cafes; ticket offices become museums. A manager from ScotRail initiated and oversees the scheme (John Y), liaises between the adoption groups and the firm and provides advice and support. 


\section{Methods}

To ensure that we collected data to best represent the quantity and variety of adoptions we opted for an ethnographic approach (Geertz, 1973) utilizing a range of data collection methods (Thompson et al., 2012, Mote and Whitestone, 2011). We spent extended time in the field (3 years) visiting stations and witnessing first-hand the work of the station adopters.

Our main source of data was in-depth interviews with station adopters, ScotRail staff and other stakeholders indirectly involved with the scheme. Our gatekeeper to the scheme was John Y, who recommended 5 stations for a pilot study. Building on this, we followed a data collection strategy which targeted 19 adopted stations which represented a wide range of adoption activities and a broad geographic and socio-economic dispersal (see table 1 for further detail on each station). Station visits lasted between a few hours to a 2 night stay. We designed visits around the station and the local area. On occasions, this allowed us to engage in impromptu conversations with other community members such as restaurant owners or employees in local retail outlets or tourist attractions. Face to face interviews were conducted either with individuals or groups in line with the adoption project. We spoke to over 100 respondents for the study; 40 were formally interviewed and each interview was digitally recorded with the participants' permission. The data equates to over 300 pages of transcribed material. We were also involved in a wide range of participant and non-participant observation activities throughout the duration of the project. This included speaking at annual adopter's lunches, attending press launches and exhibition which yielded over 60 informal conversations recorded as field notes. To gain a broader perspective we distributed an email interview to all adopters which generated an additional 23 responses. We also used photographs and video to build a visual profile of each station (we collected 850 photos and over 6 hours of video footage). 
Additional textual data was also collected including adoption webpages, leaflets and brochures, newspaper articles and specialist books. Throughout the project the research team had regular discussions relating to emergent themes within the data. When the collection phase concluded both researchers agreed an analysis strategy centred on a process of open and then selective coding (Strauss and Corbin, 1998). An initial set of codes were agreed by the researchers and then the data analyzed separately using NVivo 9. Initial coding agreement was then assessed and results compared allowing the filtering and refinement of the coding set. A selection of codes and quotes were also shown to colleagues for validity purposes. We then followed a hermeneutic approach to data interpretation with each station evaluated in isolation to allow a comprehensive overview of the adoption process. Data was then compared across stations to identify common themes.

\section{Adopt A Station enables 'placefullness'}

We discuss the mechanisms which enable community involvement in the scheme and their effects on stations through two themes; legitimacy, ownership and appropriation and from placelessness to placefullness. These illustrate processes which allow the community to make a meaningful impact and create a sense of place at stations. We present our research themes alongside mini-case studies which reveal more detail about the work of adopters.

\subsection{Legitimacy, Ownership and Appropriation}

Non-places often emerge as a result of societal homogenisation; high streets all have the same shops and architecture is standardised or internationalised. Although ScotRail retain brand representations (colour scheme, logo etc.) they recognise the need to legitimise communities to change the appearance of stations. Within an industry where consistency is often seen as axiomatic, the involvement of communities allows a more flexible approach to station appearance. The arrangements for selecting adopters are rather ad hoc and tend to involve 
self-selection when groups or individuals who are interested in station adoption contact the firm. Occasionally, JohnY initiates the adoption by making contact with local residents who he thinks may be interested in the scheme.

Adoption activities are expected to conform to company standards of health and safety.

These, however, were not viewed as onerous by participants and still afforded considerable degrees of flexibility in adoption activities. Figure one highlights the case of Wemyss Bay where a formalised 'friends' group engage in a wide range of activities at the station. 


\section{Wemyss Bay}

Wemyss Bay is a station built in the Edwardian era on the West Coast of Scotland. It plays a key role in linking the train from Glasgow with the ferry to the neighbouring island of Bute. The station is adopted by 'The Friends of Wemyss Bay Station' who operate a second hand bookshop in two old waiting rooms with an art gallery/heritage centre in a $3^{\text {rd}}$; organize an impressive array of flowers and, more recently, created a community allotment project in part of the station. This was enabled through the setting up of a charitable group:

So once we got the constitution finished we formed a kind of management group, a core group, there were five of us to run the place and we had a public awareness day, again another of John's ideas where we had about 100 people signed up to become "Friends" and that gave us some money. (Nancy, Wemyss Bay)

The group can boast over 500 'friends' who pay a small subscription which enables them to start other projects and work towards the upkeep of the station. This formalisation (including annual meetings, mail outs and a website) legitimises the group who are, as a result, able to make further improvements.

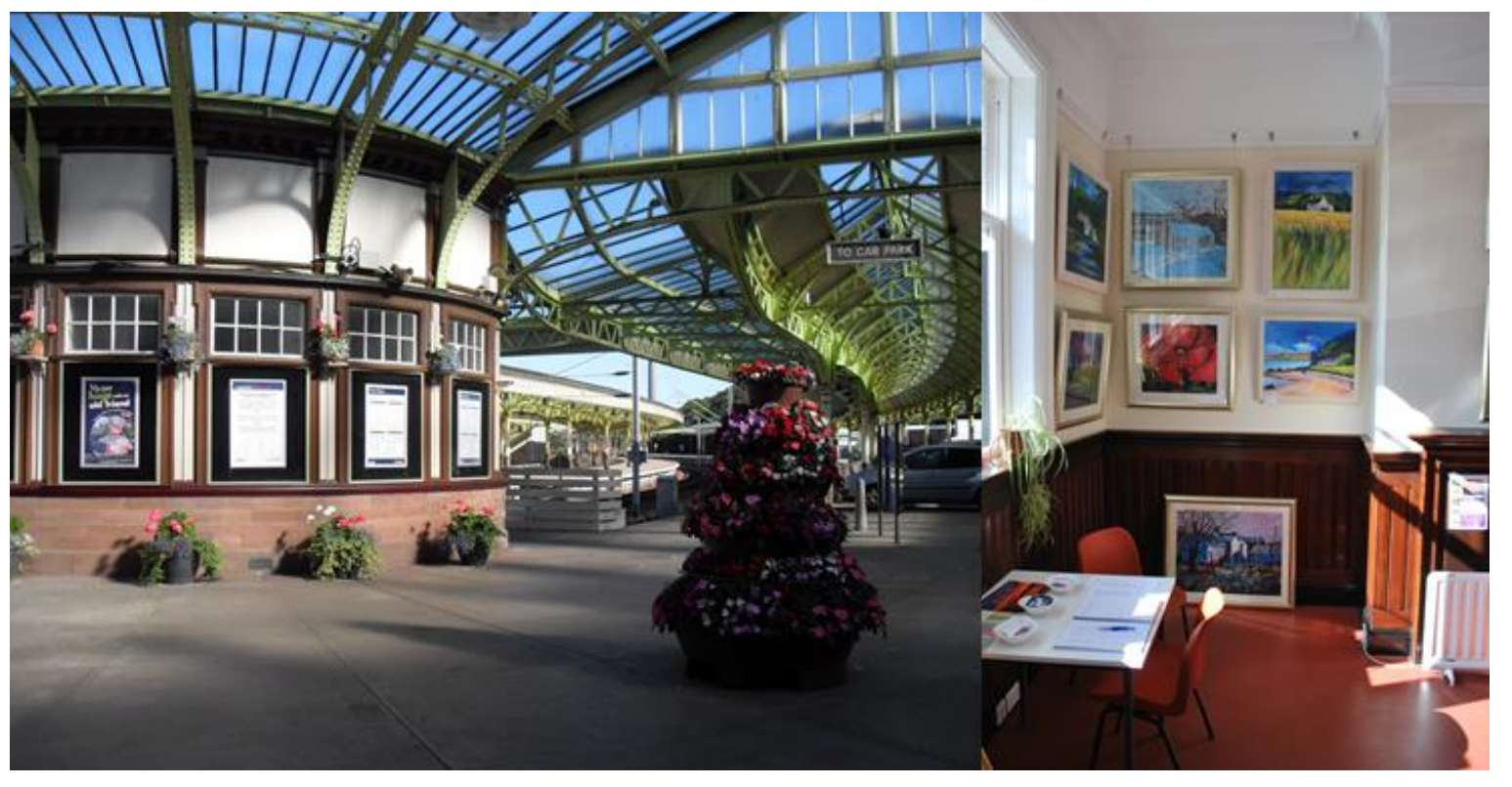

Figure 1 Wemyss Bay Case

The 'legitimate' status gained by groups as a result of their involvement in the scheme

affords them a bigger say in decisions regarding the station, for example at Barrhead in

Glasgow the local high school displays pupils' work through posters around the station but:

There had been complaints from the local community about rubbish and the Planning

Department had decided to put in a new bin and ScotRail put them in touch with the school, and they asked us to help choose the style of bin... [and] put a design on it, and it was taken from a mosaic design that the kids were working on in the school ... so again it was another wee link, the station, the local community and the council. (Lindsay, Barrhead) 
The sense of ownership results in positive action to improve the station environment and this included fencing off areas so more flowers could be planted, sourcing a seagull proof bin for a seaside station and changing the colour scheme of stations. Clearly the firm is involved in these decisions but it appears that many of the adopters are the driving force whether it be flower tubs, benches or even station appearance. When conflicts arise it is perhaps the opinion of the adopters that has the greatest weight.

Our findings indicate instances of conflict are relatively rare. For adopters, downsides were minor and the only examples we found were linked to the need for patience when dealing with the various railway bodies. To illustrate, one adopter commented that "wheels move slowly" whilst another referred to how they hit a "low spot" when the station lights were out for "an embarrassingly long time." Despite the potential for disagreement, legitimising and empowering the local communities to be involved appeared to have benefits for both firm and adoption groups. In remote parts of Scotland, rationalization during the 1980's left many stations unmanned which created a sense of placelessness leading to a lack of care over the environment and stations falling into disrepair. Adoption means that these parts of the network are now looked after, albeit by volunteer adopters rather than paid employees:

In 1986 the station was de-manned because of a re-signalling scheme so no-one was employed here anymore... If you go to a number of places along this line you will see that there are very few young communities because the employment has gone, the railway was the employer. We are here all day, we keep it tidy, we keep an eye on safety. (Steve, Bridge of Orchy)

Doing gardening at your own station does allow you to feel that you are station master of that patch and you will of course meet people who will say 'what time is the next train to Glasgow?' or whatever so you will feel like it and yet you are doing something which we recognise...I think there's that motivation of becoming involved or retaining involvement at a personal level (John, ScotRail)

This gives the adopters the status of custodians who protect and conserve stations through their presence and activities, something recognised by the railway heritage trust, 'from the 
point of view of the rail industry it is good politics to look after your heritage' (Andy,

Director, Railway Heritage Trust). We encountered several examples where railway

employees were resistant to adopters' custodian status. One adopter commented on how some employees are keen to limit adopters' activities so it does not impact on their own

opportunities for overtime. At another station railway employees refused to give adopters the toilet key to allow a copy to be made. Figure two offers a further example of custodianship at Glenfinnan Station.

\section{Glenfinnan}

Glenfinnan is a small station on the West Highland Line, a popular tourist destination with its association with Bonnie Prince Charlie and the Jacobite rebellion in the 18th century. It is also close to the Glenfinnan Viaduct made famous by the Harry Potter movies. The station is adopted by John and Hege Barnes who have been working at Glenfinnan for over 20 years and hold the lease for the station buildings. The station, when they started, was in a state of some disrepair. When I first came here in 1990 all the stations on the line were very run down (John). Now, the couple live at the station which has two disused railway carriages which operate as a café and bunkhouse respectively. The station also has a small museum in the station building, education facility in the original signal box, renovated water tower, snow plough and a wide range of plants and flowers. The couple raised over $£ 500 \mathrm{k}$ to renovate the station and view themselves as custodians of this local asset.

I think it is local individuals in the community, isn't it, someone has got to be extremely enthusiastic about it, to be able to carry it forward and then it will work. (John)

Well the fact that we are there, the museum is there, I think, well obviously it means that the site is looked after properly and the buildings are looked after properly (Hege)

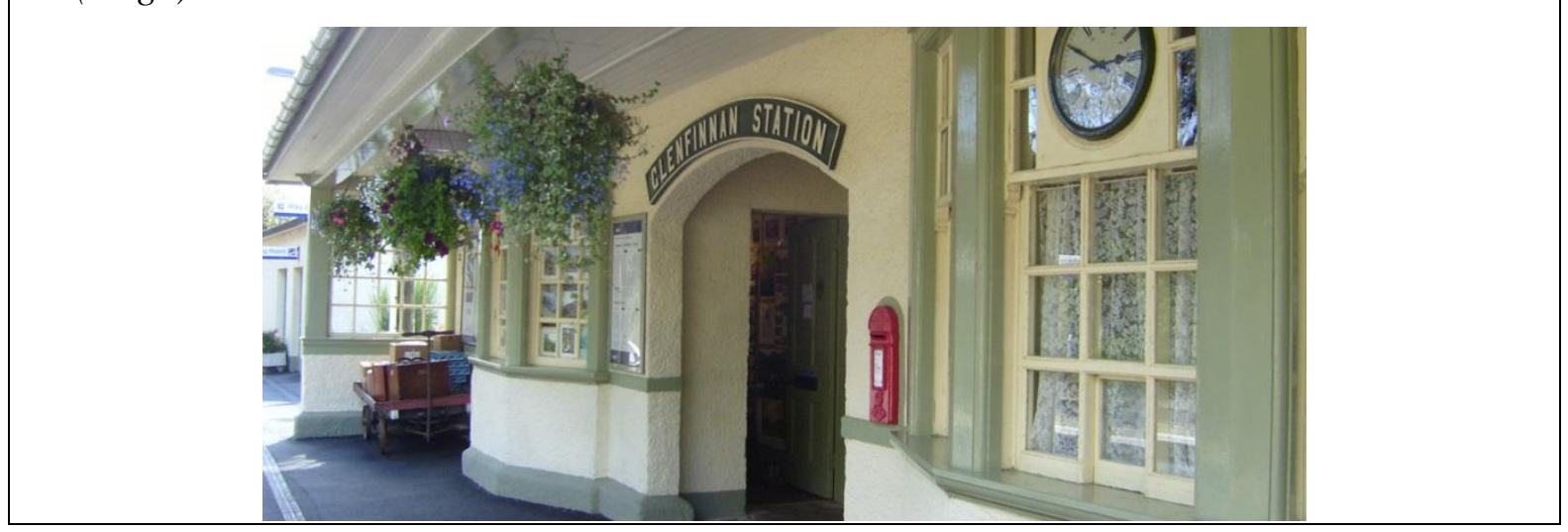

Figure 2 Glenfinnan Case

It would perhaps be easy to look at legitimisation and empowerment in a cynical way, the

firm exploiting communities to undertake work previously the responsibility of station staff. 
However, although adopters were under no illusions about the benefits that ScotRail gained from their involvement, it was clear that station adoption contributed to a much wider personal or community well-being agenda which the following quotes illustrate:

They don't have to pay wages so that would be the most economical way of looking at it, they have got somebody or a team of people that are prepared to look after the premises that years ago station staff would have done... [But] from my point of view, the things that it has led on to, even though it is a voluntary job, would not have happened had it not been for me being on the railway station the hours that I am. So it works both ways and for me it gives me enormous pleasure. (Sonia, Mallaig/Arisaig)

I have noticed that when I involve others they often feel better about themselves and so I have invited people who might find it difficult to get regular employment to help me. People have described gaining better health, confidence and a sense of wellbeing through helping with the plants at the stations. (Louis, Stranraer To Ayr, Email)

Appropriation of stations stems from a number of motivators. In some cases the station is appropriated 'as an extension of activities elsewhere in the town' so the station is a component in a wider community agenda to make a more meaningful place for visitors and residents (discussed in the subsequent section). Figure three shows an example of this at Pitlochry station: 


\section{Pitlochry}

Pitlochry is a popular tourist town in the central highlands of Scotland. The station has been the subject of a 'liaison group' for nearly 20 years but has been adopted by 'Pitlochry in Bloom' and 'The Pitlochry Station Bookshop' since 2005. Pitlochry in Bloom are involved in gardening activity across the town, from hanging baskets on the high street to planting bulbs on access roads. At the station a sculpture of a station master displays the sign 'Welcome to Pitlochry in Bloom' and this is indicative of the role played by the group in the town at large and the appropriation of the station by the group. Vandalism is almost non-existent, something attributed to the success of the group amongst local school pupils who are engaged in planting and litter picks:

I think we get a bit of what I am going to call "high jinx" you know somebody might want to swing on a hanging basket on the way home when they have had a pint too much, but they usually come to apologise the next morning, or they very carefully put it behind the wall (Sally).

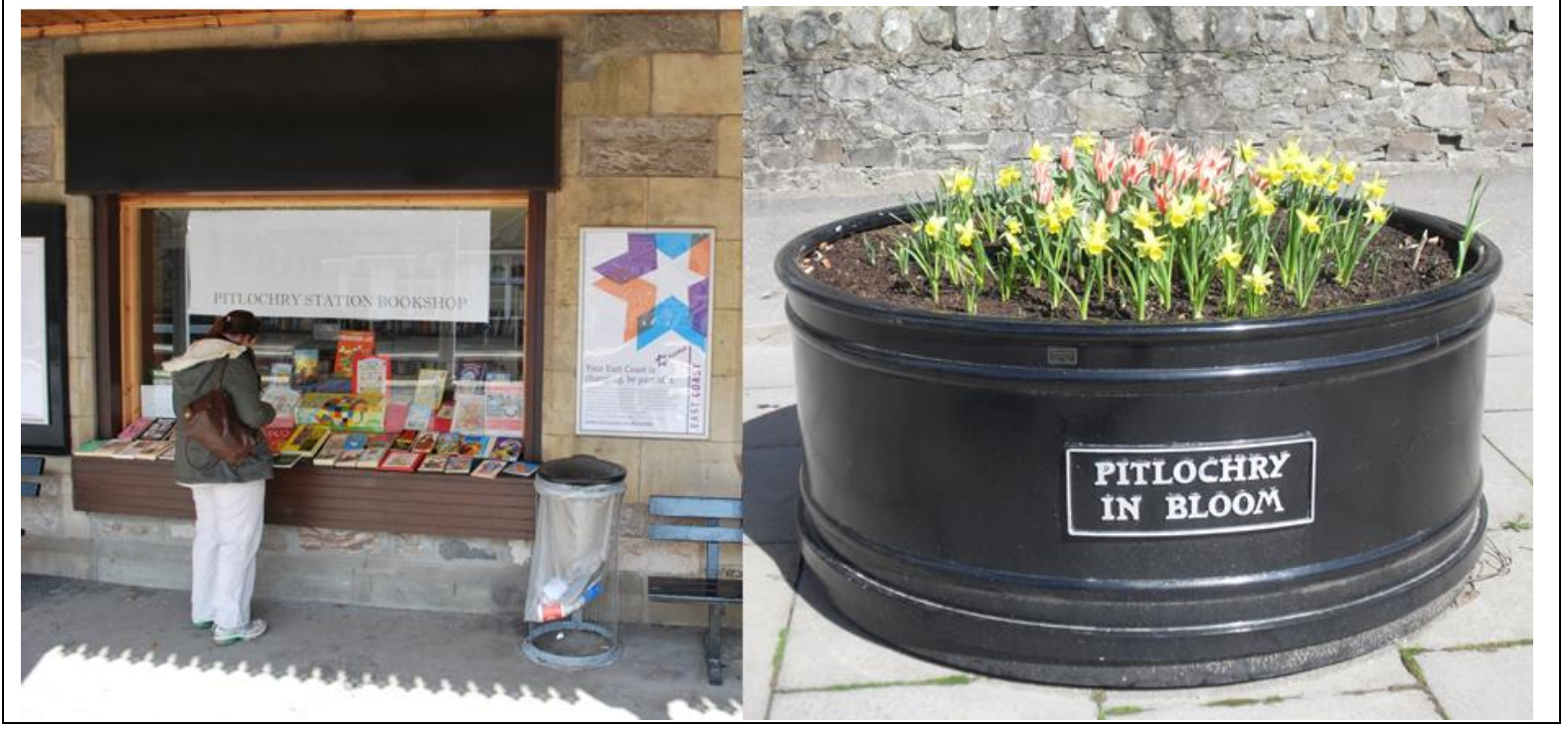

Figure 3 Pitlochry Case

In other cases, adopters' appropriate station buildings as a useful space for a particular activity. Model railway clubs, second hand bookshops and heritage centres all fit well within the station environment, these individuals appropriate through necessity and convenience like artist Kirsty Lorenz at Ladybank in Fife:

Art Studios are quite hard to find, I had spoken to John initially and he told me about the scheme and I thought that would work out, he said go back and see Marjorie (Station Master) who got the big keys out and showed me all the rooms and we came in here, it was filthy and semi-derelict and I just could not believe it, I was jumping up and down, thinking this is amazing, this is amazing (Kirsty, Ladybank) 
Appropriation leads to an increased sense of ownership of the station as part of a community

or in some cases 'the centre of the community,' something which resonates at Kinghorn

station in figure four.

\section{Kinghorn}

Kinghorn is a small town on the coast of Fife across the Firth of Forth from Edinburgh.

The station is adopted by Lynette Gray who retired from her job as a teacher to open an art gallery and studio at the station. This required a herculean effort to make the somewhat down at heel station master's house and waiting areas both habitable and suitable for Lynette's new career as an artist (see before and after photos below). In 2015 Kinghorn train station was named the best in the country by Keep Scotland Beautiful.

we started clearing the place [station building], filling skips with rubbish and eventually I just started to renovate it... [outside area] wasn't in a good condition at the time, what I have been doing is I have been taking up a bit of bed, replacing it, and putting in about 16 bags of compost and rose fertiliser and goodness knows what, but it will look gorgeous when I am finished. I have also got a horrible area which is going to be my car park, we are going to put a wee garden there and that will transform it because it is a tip really, but that has just been vacant for ages...I am gradually getting there and I am keeping on top of the garden just to keep it looking nice, but it is appreciated and people like it.

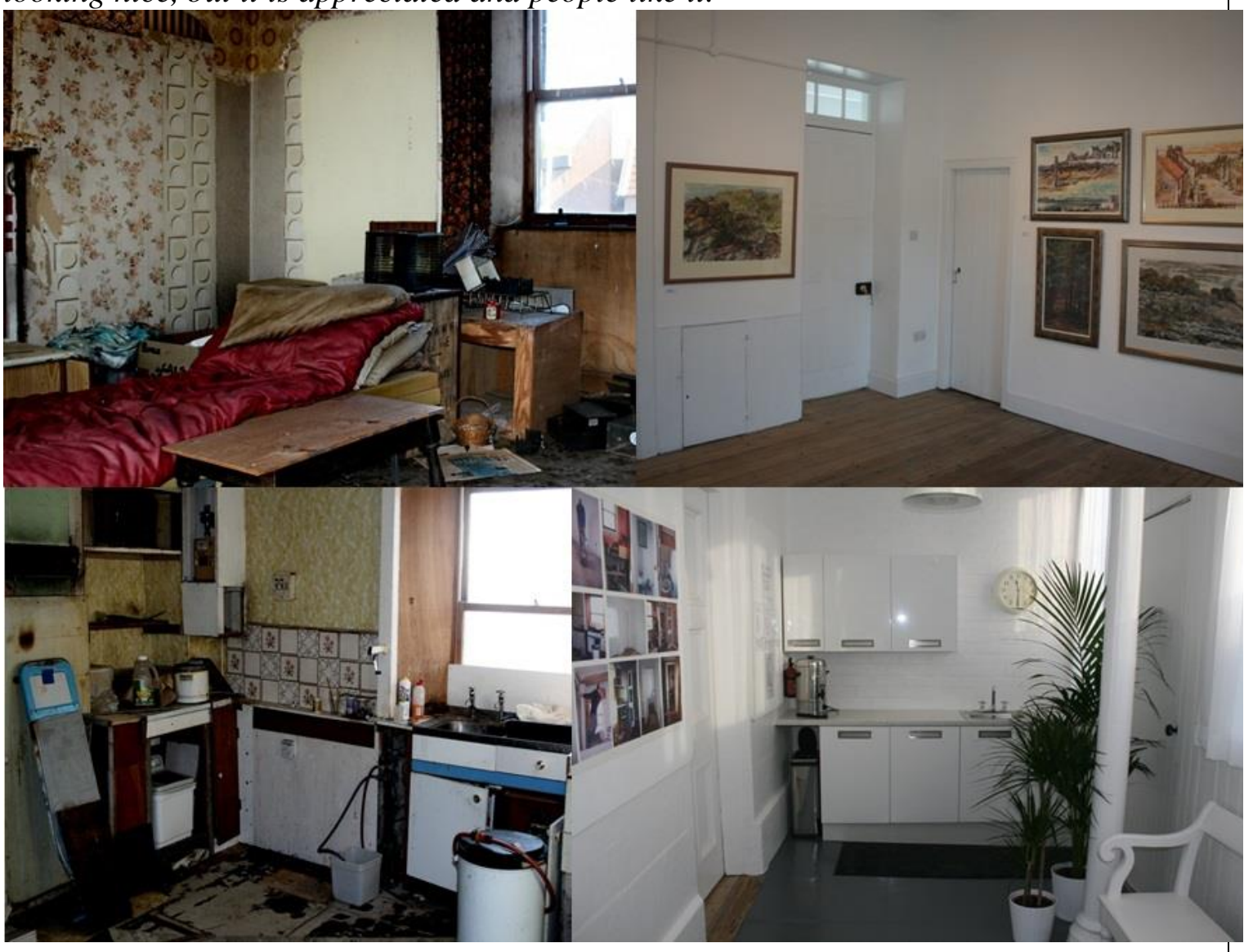

Figure 4 Kinghorn Case 
A sense of ownership leads to feelings of responsibility and an eye for the future, crucially it means that adopters engender and develop a sense of place. Adopt a Station is enabled by the flexible, 'hands-off' approach of the firm. They recognise the benefits that they can gain from community involvement (ScotRail has reduced their annual fine for failures in service quality from around $£ 1$ million per annum in 2009 to around $£ 250,000$ in 2012 ), however labelling the scheme as exploitative would seem short sighted as the adopters benefit through legitimisation, ownership and appropriation. The following section shows how adopters convert stations from non-places to something placeful for the community.

\subsection{From placelessness to placefullness}

\section{A dismal place is now welcoming (Campbell, Alness, Email)}

Central within our study was the overwhelming sense of place transformation that resulted from the adoption process. The station role as a non-place or representative of placelessness is understood by firm and community both in terms of a homogenised environment but also as poor reflections of the associated community:

I just think that rail stations and bus stations and airports, they have got to look welcoming, it is horrible going into a - I mean there is nothing like Crewe station at 3 in the morning, you know, it is actually dreadful, there are some really dreadful stations ...I think it reflects on the town if the station is beautiful and in a nice state. (Allan, Stonehaven)

The strong community reaction to placelessness (encouraged and enabled through the processes outlined earlier) and the opportunities afforded by schemes such as Adopt a Station are key ingredients to recapturing a sense of place. Figure five demonstrates the effect of change at Invergordon station. 


\section{Invergordon}

Invergordon is a former industrial town in the far north east of Scotland. Inspired by a fomer logging town in Canada they became a 'mural town' with various buildings in Invergordon decorated with large murals depicting elements of the town's heritage or existing activities. As part of the project the station was adopted and a mural called 'The Long Goodbye' was commissioned (see images below). The work depicts the Seaforth Highlanders regiment leaving Invergordon in 1939 to fight in World War II. Eight different community groups are also involved in gardening at the station. This has transformed the station from a rather undesirable environment:

Anne: When you think about what it was like, it was dismal, really dismal; there was nothing, absolutely nothing.

Wilma: But it was worse than that, it was a scary place, you would not, if you did not have to go to use it, you wouldn't, if you could go by car you would go by car to wherever you were going rather than going down to that station, particularly in the winter days when it was dark early, it was a horrible place.

And as a result of adoption:

Anne: I think for the locals it is an eyesore that has been taken away; it is now something to be proud of.

Wilma: People do mention it; they will come into my work and say, ooh that is nice, they [the flowers] look really good this year, you know, so people enjoy looking at it now rather than walking past it and thinking what an eyesore, what a tip.

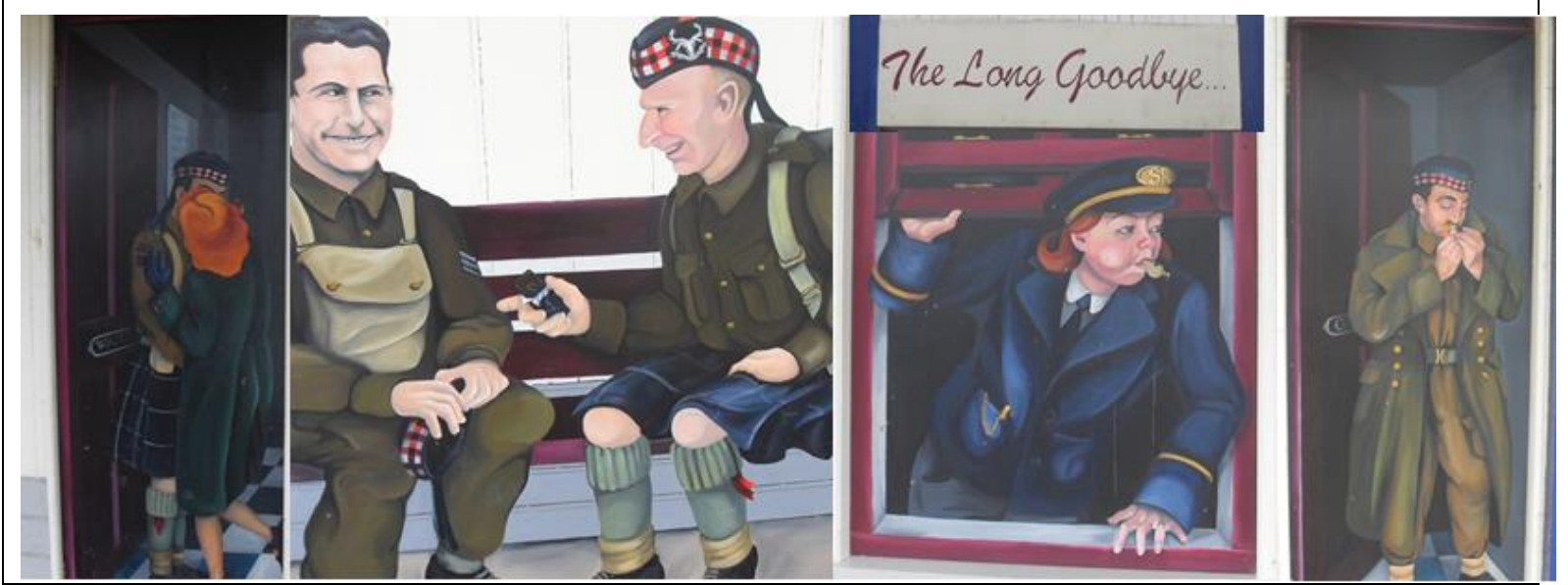

Figure 5 Invergordon Case

In its most simple form, adopters captured a sense of placefullness through occupation of

non-places, Kirsty's art studio at Ladybank is a good example of this:

There is no member of staff here during the day from 10am in the morning, it can be a bit 'tumbleweedy' and it is quite a quiet station, ...I think me being here has made a shift in energy with it, I don't know, it makes it more interesting. (Kirsty, Ladybank)

Alongside the aesthetic and physical transformation of the stations, another outcome of the legitimacy, ownership and appropriation processes is a transformation in how the community 
views the station. Through adoption citizens come to see stations more as community assets than transport hubs:

Once again we can be the First Class Second Hand Bookshop at Wemyss Bay Station, a haven in bad weather, providing information about parking tickets, ferry tickets, train tickets, as well as real bargains in books, and perhaps, in days to come, cuttings of geraniums, or even a few surplus tomatoes (Nancy, Wemyss Bay).

In our research placefullness is deeply rooted in the community, its heritage and the pride for its public goods. Recapturing a sense of community was for many adopters the first sign of placefullness which can, potentially, manifest itself in a variety of ways:

[We wanted to] do something useful in order to make Johnstone more attractive to its inhabitants, commuters using the station and passengers passing through the area to and from other destinations. To make the use of the trains a more pleasant experience and thus encourage train travel which will in turn help to retain the station and its links to other places and; to encourage a sense of community by encouraging friends and neighbours to grow and donate plants for "our" station. (Stephen, Johnstone, Email) The process of appropriation gives communities an opportunity to gain access to and stamp the community's identity onto a valuable public good. A sense of community and a little friendly competition can have a positive effect where citizens are inspired by community work and motivated to get involved.

Placefullness is also related to reinforcing the particular heritage of a location and ensuring this is protected for future generations. In Wemyss Bay this could be a display of the original architectural plans of the station; in North Berwick a floral display incorporating lobster pots nods to the town's maritime heritage; and in Cupar a dedicated heritage centre in the old station masters flat. At Invergordon the mural elicits strong emotional responses:

I remember when we had the opening ceremony [and] there was huge emotion, there was not a dry eye in the place, [the mural has] a strong connection because if you look at the War Memorial here there were so many of the local guys, the Seaforths, and I think there was something like only one in ten who came back after the war (Wilma, Invergordon). 
Placefullness also seemed to be represented by a rebirth of pride in the community. The activities of the adopters being recognised appreciated and attributed to community efforts played an important role in motivating these activities:

I think people take a sense of pride in the local community and so when we have 20 pupils with schoolwork displayed [posters at the station] people walking through on a daily basis will say, that is wee Jeanie's grandson that did that bit there, he is at the High School, it is a conversation point and I think it encourages people to use the station, I would like to think that it does. (Lynsey, Barrhead)

The community may feel that the station reflects their pride in the town and that visitors to the town will get a good impression. It is significant that over a period of 6 years there has been practically no vandalism to the tubs or theft of flowers. (Kathleen, Helensburgh)

This sense of pride can also be seen in the activities at Whitecraigs station in figure six:

\section{Whitecraigs}

Whitecraigs is a suburban station in the south side of Glasgow. It is adopted by Peter McKinley who treats the station as an extension of my back garden. Peter has received several awards for his flowers and recognises the benefits of adoption both for himself and the wider community.

Well when I do come down on a Saturday quite a lot of people come up to me and just ask me who I am and say, well done it is really good, the station is looking fantastic, somebody said that it looked like a toy town station, so it is quite nice.

I would be disappointed if somebody came along and ripped it apart or if the scheme stopped or something, I am quite proud of it.

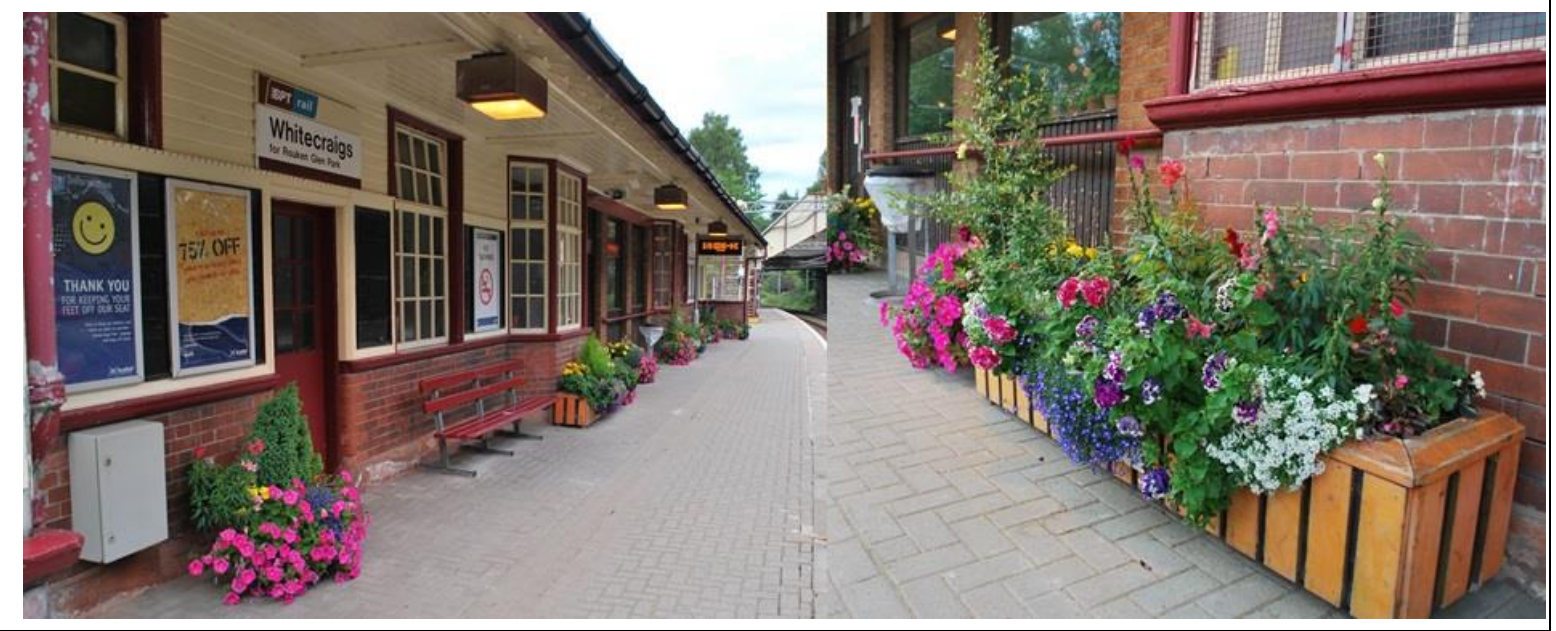

Figure 6 Whitecraigs Case 
Finally, a sense of placefullness is about community representation to the outside world. The railway station was seen as playing a critical role in the community as a gateway or 'shop window.' One respondent recognised that 'many people's only experience of certain towns is passing through them on the train' and the shop window is perhaps then a reflection of the pride of the community. This was a common theme within many of the interviews that people cared about how others perceived their community. In towns and villages associated with tourists this gateway role was particularly vital:

For the tourists, I think just arriving at the station and the way it looks, it says

Welcome, you have got welcome signs on both sides and it is always very clean (Sally, Pitlochry)

Hopefully people who are passing through on the train might see the planters, the murals and think oh that is a nice wee town, let's go and visit this one. (Wilma, Invergordon)

Gateways create a positive first impression of a community, a representation of its placefullness which can engender a sense of wellbeing amongst citizens and serve to represent the community to the outside world in a more positive light and in turn increase visitors' satisfaction.

\section{Conclusions}

The railway station performs a wide range of societal functions (Edwards, 1997), often associated with the context of larger, city centre, stations and in relation to the potential for a station to be a location for various retail or services industries (Pels and Rietveld, 2007, de Graaff et al., 2007). Our research sees stations (outside of the city centre) as playing an equally vital role within smaller, discrete communities. In that sense we present a response to the dilemma posed by Bishop (2002) that railways can be seen as either destroying a sense of place or enabling connections to be made. Our findings suggest the latter, Adopt a Station allows the rail company to connect with local communities and for communities to connect 
with each other, and the outside world. The railway station can therefore be resurrected as a place which acts as a seismograph of 'societal vibrations and convulsions' (Dethier, 1981 page 10$)$.

The sense of place created by communities is also important because each station is unique. This combats notions of placelessness associated with standardisation and rationalization of inhabited spaces including both urban centres and transport hubs (Warnaby, 2009b, Warnaby, 2009a). Our lives are dominated by consumption spaces which despite attempts at creating a façade of community (Belk and Bryce, 1993) are purveyors of the placeless. Adopt a Station benefits from an enlightened approach by a firm who recognise the benefits that can be derived from allowing the community to appropriate stations and gain a sense of ownership.

For the community, station adoption presents a wealth of opportunities. The scheme's flexibility appears critical, whether the need is for a brighter, more aesthetic environment or a more structured and intense form of custodianship, the ambitions of adopters are only limited by the stations themselves. For the firm benefits are also clear and reflect existing literature on railway station improvement with the added dimension that improvements are enacted and maintained by the people most likely to use the railway and therefore benefits are self-derived and more relevant. Engaging with local communities (often involving younger community members) engenders a sense of care and pride and reduces vandalism (Thompson et al., 2012). The lack of vandalism at adopted stations was a strong theme in our study and in most cases it was due to the quick response of adopters (they pull out a flower, we put it straight back) and the care and attention shown.

This level of care also creates environments that are aesthetically pleasing and provide other forms of hedonic value to passengers (Cascetta and Cartenì, 2014). The presence of museums, heritage centres, artwork and murals, bookshops and renovated architecture all 
contribute to the value that passengers will derive from their time spent on the station and is likely, therefore, to contribute to overall satisfaction with the railway experience. The community led improvements at the stations also fit with the mobilities paradigm and the notion that the journey is experiential (Bissell, 2009). Railway stations, therefore, fit into a wider travel experience making the 'non-place' tag less relevant. Our research demonstrates how legitimized community involvement means railway can shake off the tag of non-places (Augé, 2008) that have lost their meaning; rather shared appropriation of these sites leads to changes in the stations themselves (physical improvements, new facilities, aesthetic appeal) and in turn to the sense of community and attachment felt towards them.

Previous research on place-making often overlooks the underpinnings of effective civic engagement. Research has focused on resistant consumers who 'sidestep' constraints of bureaucracy and market economics in order to create connectedness between people and their environment (Visconti et al., 2010). Our work contributes by showing how a sense of place, indeed placefullness, is not only possible within a 'market' led environment but it is here that citizens can be legitimised in their activities. We would agree that localisation (or placefullness) is fundamentally about the ability to retain a sense of the local (Värlander, 2007). However, we suggest that placefullness that is firm enacted will never offer more than the ghost of the local and true placefullness needs the active and empowered input of those who understand place best - the community.

\subsection{Limitations and Future Research}

This study was focussed on the activities of the adopters themselves and on that basis no additional members of the communities involved were interviewed. However there is some evidence that station adoption does improve passenger satisfaction (reference withheld for review) and this is certainly an area that would merit further research in the future. As has been indicated by our examples the effort involved in station adoption is not insignificant and 
although the scheme has now been running (and growing) successfully for nearly 10 years retaining a sense of ownership within the community may be a challenge. A follow up study may reveal the extent to which communities can maintain enthusiasm and encourage younger generations to become involved. As noted earlier, there was limited evidence of conflict in our data and indeed, respondents downplayed any downsides or problems with the scheme. However, JohnY recounted a few examples of adoption ideas that did not come to fruition. This was either due to expensive demands from adopters that the firm refused to fund (e.g. self-watering planters that would cost thousands of pounds) or over ambitious plans for empty buildings. Further detail on these unsuccessful projects would have been a useful addition to our data.

The station sample used within our research may appear to limit the research and does, to an extent bind the findings to smaller stations. However, there are perfectly pragmatic reasons for this: firstly in our sample larger 'inter-city' stations were not operated by ScotRail and so couldn't participate with the scheme; secondly, the communities around larger city centre stations are perhaps more heterogeneous or transient and less likely to coalesce around a focal object; thirdly, major city centre stations tend to have a more commercial focus (Pels and Rietveld, 2007, de Graaff et al., 2007) so community driven activities would, no doubt, appear less attractive. That said, some of the stations in our sample (e.g. Wemyss Bay) are large stations with multiple occupants and others in the scheme are located in larger towns. Our sample represents both urban and rural stations suggesting that relative size or location is not a limiting factor. However, the effect of adoption on different types of communities and relative size of station would be interesting to explore in the future. 


\subsection{Implications}

The modern rail industry is associated with an often complex management structure. In the world of franchised and privatised rail services ownership is a tenuous concept when track, station, and rolling stock may all be owned or leased by different organisations. However in this environment of shifting, transient ownership the one constant feature is the community around stations. By giving communities the opportunity to claim some form of ownership the rail industry can, by the evidence of this study, both protect their infrastructure and create hedonic value at stations affording a safer, more accessible environment and potentially encourage more of the community to choose rail travel.

Writers about railway stations have always had an awareness of their role as a gateway but more in a sense of a gateway which facilitates departure. For the designers of station buildings of the $19^{\text {th }}$ and early $20^{\text {th }}$ century the architecture and embellishments that characterised the boom years of the railway industry were about making a statement about rail travel, and the companies involved. Our research suggests that for many local stations these gateways are more about looking inward; both for the community but also to visitors, and in this sense railway stations can be a true reflection of a community. 


\section{References}

ARNSTEIN, S. 1969. A ladder of citizen participation. Journal of the American Institute of Planners, 35, 4, 216-224.

AUGÉ, M. 2008. Non-Places: An Introduction to Supermodernity, London and New York, Verso.

BELK, R. W. \& BRYCE, W. 1993. Christmas shopping scenes: from modern miracle to postmodern mall. International Journal of Research in Marketing, 10, 277-296.

BISHOP, P. 2002. Gathering the land: the Alice Springs to Darwin rail corridor. Environment and Planning D, 20, 295-318.

BISSELL, D. 2009. Conceptualising differently-mobile passengers: geographies of everyday encumbrance in the railway station. Social \& Cultural Geography, 10, 173-195.

BRAND, R. \& GAFFIKIN, F. 2007. Collaborative planning in an uncollaborative world. Planning Theory, 6, 3, 282-313.

BRONS, M., GIVONI, M. \& RIETVELD, P. 2009. Access to railway stations and its potential in increasing rail use. Transportation Research Part A: Policy and Practice, 43, 136-149.

CASCETTA, E. \& CARTENİ, A. 2014. The hedonic value of railways terminals. A quantitative analysis of the impact of stations quality on travellers behaviour. Transportation Research Part A: Policy and Practice, 61, 41-52.

DE GRAAFF, T., DE GROOT, H. L. F., RODENBURG, C. A. \& VERHOEF, E. T. 2007. The WTP for facilities at the Amsterdam Zuidas. Environment and Planning A, 39, 2099.

DETHIER, J. 1981. All stations: a journey through 150 years of railway history, London, Thames and Hudson. 
EDWARDS, B. 1997. The modern station: new approaches to railway architecture, Oxford, Taylor \& Francis.

GEERTZ, C. 1973. The interpretation of cultures: Selected essays, New York, Basic Books HARRISON, H. A. 1981. Subway Art and the Public Use of Arts Committee. Archives of American Art Journal, 21, 3-12.

HEALEY, P. 1997. Collaborative Planning: Shaping Places in Fragmented Societies, London, Macmillan.

HEALEY, P. 2003. Collaborative planning in perspective. Planning Theory, 2, 2, 101-123.

LEE, R. 2003. Potential railway world heritage sites in Asia and the Pacific. Institute of Railway Studies, University of York.

LIPPARD, L. R. 1997. The lure of the local, New York, The New Press

MAILLARD, M. 2001. Three New French TGV Stations. Japanese Railway and Transport Review, 28, 26-28.

MOTE, J. E. \& WHITESTONE, Y. 2011. The social context of informal commuting: Slugs, strangers and structuration. Transportation Research Part A: Policy and Practice, 45, 258-268.

PELS, E. \& RIETVELD, P. 2007. Railway stations and urban dynamics. Environment and Planning A, 39, 2043-2047.

SCOTRAIL. 2012. Adopt a Station [Online]. Available: www.scotrail.co.uk/content/adopt-astation [Accessed 31st May 2012].

SEAMON, D. \& SOWERS, J. 2008. Place and placelessness, Edward Relph. In: HUBBARD, P., KITCHEN, R. \& VALLENTINE, G. (eds.) Key texts in human geography. London: Sage. 
SHANDAS, V. \& MESSER, B. 2008. Fostering green communities through civic engagement: community-based environmental stewardship in the Portland area. Journal of the American Planning Association, 74, 4, 408-418.

STRATTON, M. 2000. Industrial buildings: conservation and regeneration, Taylor \& Francis.

STRAUSS, A. L. \& CORBIN, J. M. 1998. Basics of qualitative research: Techniques and procedures for developing grounded theory, Thousand Oaks, CA, Sage Publications, Inc.

SUSSKIND, L. \& ELLIOTT, M. 1983 Paternalism, conflict, and coproduction: learning from citizen action and citizen engagement in Western Europe. In: SUSSKIND, L., ELLIOTT, M. \& ASSOCIATES (eds.) Paternalism, conflict, and coproduction: learning from citizen action and citizen engagement in Western Europe. New York, Springer Science and Business Media.

THOMPSON, K., OFFLER, N., HIRSCH, L., EVERY, D., THOMAS, M. J. \& DAWSON, D. 2012. From broken windows to a renovated research agenda: A review of the literature on vandalism and graffiti in the rail industry. Transportation Research Part A: Policy and Practice, 46, 1280-1290.

VÄRLANDER, S. 2007. The Role of Local Strategies on a Globalizing Market An Exploration of Two Service Industry Cases. Space and Culture, 10, 397-417.

VISCONTI, L. M., SHERRY JR, J. F., BORGHINI, S. \& ANDERSON, L. 2010. Street Art, Sweet Art? Reclaiming the "Public" in Public Place. Journal of Consumer Research, $37,511-529$.

VON BUCH, A. 2007. In the image of the Grand Tour: Railway station embellishment and the origins of mass tourism. The Journal of Transport History, 28, 252-271. 
WARNABY, G. 2009a. Look up! Retailing, historic architecture and city centre distinctiveness. Cities, 26, 287-292.

WARNABY, G. 2009b. Non-place marketing: transport hubs as gateways, flagships and symbols? Journal of Place Management and Development, 2, 211-219.

WILLIAMS, P. W., GILL, A. M. \& CHURA, N. 2004. Branding mountain destinations: The battle for "placefulness". Tourism Review, 59, 6-15.

WOLMAR, C. 2007. Fire \& steam: how the railways transformed Britain, London, Atlantic Books. 
Table 1 - Station sample: additional information

\begin{tabular}{|c|c|c|c|}
\hline Station & Adoption Activities & Adopter* & Funding** \\
\hline Arisaig & $\begin{array}{l}\text { West Highland Line station visited by the 'Jacobite Steam Train' during } \\
\text { the summer. Also features community meeting room and gardening. }\end{array}$ & Individual & \\
\hline Bridge of Orchy & $\begin{array}{l}\text { West Highland Line station featuring bunkhouse in original 'Swiss } \\
\text { Chalet' building on platform and gardening. }\end{array}$ & Business & \\
\hline Crianlarich & Station tearoom since 1900 and gardening on platform & Business & \\
\hline Cupar & $\begin{array}{l}\text { A heritage centre located former station masters flat. Extensive } \\
\text { gardening including edible plants on station platform. }\end{array}$ & Group (x2) & $\begin{array}{l}\text { The Railway Heritage Trust, Local authority and } \\
\text { other charitable funding sources }\end{array}$ \\
\hline Invergordon & $\begin{array}{l}\text { Station mural depicts the departure of local regiment in } 1939 \text { and } \\
\text { subsequent war history, also extensive gardening. }\end{array}$ & Groups (multiple) & $\begin{array}{l}\text { Creative Scotland and other charitable funding } \\
\text { sources }\end{array}$ \\
\hline Kinghorn & Station master flat and rooms now used as art studio, and gardening. & Individual & The Railway Heritage Trust \\
\hline Mallaig & $\begin{array}{l}\text { West Highland Line station and final stop for the 'Jacobite Steam Train' } \\
\text { during the summer, extensive gardening. }\end{array}$ & Individual & \\
\hline Maxwell Park & $\begin{array}{l}\text { Grade 'B' station features community meeting room and exhibition } \\
\text { space; flowers maintained on platform. }\end{array}$ & Group & $\begin{array}{l}\text { Glasgow City Council and the Railway Heritage } \\
\text { Trust }\end{array}$ \\
\hline Stonehaven & Flowers and posters which advertise town's tourist facilities. & Group & Local business support \\
\hline Uddingston & Extensive Flowers and station café & Group/Business & Fundraising activities \\
\hline Wemyss Bay & $\begin{array}{l}\text { Award winning bookshop, exhibition space, community allotment, a } \\
\text { huge array of flowers. }\end{array}$ & Group & $\begin{array}{l}\text { The Railway Heritage Trust/Bookshop/ } \\
\text { Membership Scheme }\end{array}$ \\
\hline West Kilbride & Flowers and restaurant. & Group & Community Council \\
\hline Whitecraigs & Flowers and gardening around refurbished station building & Individual & \\
\hline
\end{tabular}

* Individual signifies no formally constituted group and could include both individuals and couples. Group signifies some kind of formally constituted organization

Business signifies a small business operating out of the station

**All stations will receive some funding from ScotRail, this column identifies additional funding 